\title{
PERENDAMAN EKSTRAK Spirulina plantesis TERHADAP Ig-M, JARINGAN LIMPA DAN DIFERENSIAL LEUKOSIT IKAN MAS SETELAH DIINFEKSI Aeromonas hydrophila
}

\author{
Deeping Of Extract Spirulina plantesis To Ig-M, \\ Spleen Tissue And Diferential Leucocyte Of Carp \\ After Infected By Aeromonas hydrophila.
}

\author{
Widya Pratiwi ${ }^{* 1}$, Lucia Tri Suwanti dan Woro Hastuti Satyantini \\ Prodi S2 Bioteknologi Perikanan dan Kelautan, Sekolah Pascasarjana, Universitas \\ Airlangga, Surabaya \\ e-mail: w.pratiwi91@yahoo.com*1,
}

\begin{abstract}
Abstrak
Penyakit yang sering menyerang ikan mas yaitu bakteri Aeromonas hydrophila, bakteri ini penyebab penyakit bercak merah atau Haemerrhagic Septicaemia pada ikan air tawar. Salah satu bahan alami yang dapat digunakan untuk pengendalian sistem tubuh terhadap penyakit yaitu Spirulina platensis. Penelitian ini bertujuan untuk menganalisis pengaruh ekstrak etanol Spirulina platensis terhadap respon Ig-M, diferential leukosit, histopatologi limpa yang diinfeksi bakteri Aeromonas hydrophila. Penelitian ini dilakukan dalam dua tahap uji, yaitu uji in vitro dan uji in vivo. Pada uji in vivo metode yang digunakan adalah eksperiment laboratoris dengan menggunakan 5 perlakuan yaitu kontrol positif (ikan diinfeksi A. hydrophila), kontrol negatif (ikan diberi Phospate Buffer Saline ), perendaman ekstrak dosis $50 \mathrm{ppm}$, dosis $100 \mathrm{ppm}$, dosis $200 \mathrm{ppm}$. Ikan mas diinfeksi terlebih dahulu dengan cara menyuntikkan $0,1 \mathrm{ml}$ suspense A. hydrophila sebanyak $10^{6} \mathrm{cfu} / \mathrm{ml}$ secara intramuskular. Setelah menunjukkan gejala klinis selama 2 hari, ikan direndam dengan ekstrak etanol S. platensis selama 30 menit. Perendaman dilakukan dua kali, pada hari ke 2 dan ke 5. Hasil penelitian menunjukkan bahwa ekstrak S. platensis memberikan pengaruh yang berbeda nyata $(\mathrm{p}<0.05)$ terhadap kondisi jaringan limpa, diferensial leukosit dan konsentrasi Ig-M. Ekstrak S. platensis dapat meningkatkan sistem kekebalan tubuh denga adanya peningkatan konsentrasi Ig-M dibentuk oleh proliferasi limfosit sel B. Dosis perendaman yang sudah dapat meningkatkan sistem kekebaln tubuh adalah 100 ppm dengan tingkat kelangsungan hidup tertinggi $88,8 \%$.
\end{abstract}

Kata kunci : S. platensis, A. hydrophila, histopatologi, Ig-M, diferensial leukosit

\begin{abstract}
Bacterium of disease that often attack of carp is Aeromonas hydrophila, these bacteria causative agent of Haemerrhagic Septicemia in freshwater fish. One of the natural ingredients that can be used to control of the body system against disease is Spirulina platensis. This study have a purpose to analyze the effect of ethanol extract of Spirulina platensis on the
\end{abstract}


response of Ig-M, diferential leukocytes, spleen histopathology infected bacteria Aeromonas hydrophila. This research have two test steps, are in vitro and in vivo test. In vivo test method used was a laboratory experiment using five treatments, a positive control (fish infected with A. hydrophila), negative control (fish given Phosphate Buffer Saline), immersion extract dose of $50 \mathrm{ppm}$, a dose of $100 \mathrm{ppm}, 200 \mathrm{ppm}$ dose. Carp fish was infected firstly by injection 0.1 $\mathrm{ml}$ suspension of $A$. hydrophila were $10^{6} \mathrm{cfu} / \mathrm{ml}$ in intramuscularly. After have showed clinical symptoms for 2 days, deeping fish with ethanol extract of $S$. platensis for 30 minutes. Deeping performed twice, on day of 2 and 7. The results showed that the extract of $S$. platensis provide a significantly different effect $(\mathrm{P}<0.05)$ on the condition of spleen tissue, leukocyte differential and concentration of Ig-M. S. platensis extracts can boost the immune system premises the increased concentration of Ig-M formed by the proliferation of lymphocytes B. Dose immersion would enhance the body immunity system was $100 \mathrm{ppm}$ with the highest survival rate of $88.8 \%$.

Keywords : S. plantesis, A. hydrophila, histopatology, Ig-M, diferential leucocyte.

\section{Pendahuluan}

Pembudidaya ikan sering menjumpai masalah dalam budidaya, terutama budidaya ikan secara intensif. Budidaya intensif dilakukan agar produksi yang didapat cepat dan banyak, tetapi kendala satu-satunya yang dijumpai yaitu penyakit. Penyakit yang menyerang ikan mas antara lain disebabkan oleh virus, bakteri, jamur, protozoa, dan metazoa. Bakteri merupakan penyebab kedua kematian pada ikan baik ikan air tawar, payau dan laut (Cipriano, 2001).

Motile Aeromonad Septicemia (MAS) adalah penyakit bakterial yang sering menyerang ikan air tawar. Didalam tubuh bakteri $A$. hydrophila terdapat Gen Aero yang bertanggung jawab dalam memproduksi racun aerolysin dan hemolysin dimana Aerolisin merupakan protein extraseluler yang diproduksi oleh beberapa strain A. hydrophila. Racun tersebut masuk kedalam aliran darah, menyerang organ visceral, pernapasan dan menyebabkan infeksi sekunder pada kulit (Pratheepa dan Sukarman, 2014). Alternatif dalam melawan bakteri biasanya menggunakan berbagai macam zat kimia seperti antibiotik oxytetracyclin dan erythromycin. Namun penggunaan zat kimia seperti obat-obatan mempunyai efek samping dan beberapa kelemahan yaitu dalam jangka waktu lama bakteri akan menjadi resisten dan menimbulkan pencemaran lingkungan. Salah satu bahan alternatif dari hasil laut yang dapat dikembangkan yaitu Spirulina platensis. Mikroalgae ini ditemukan memiliki senyawa fenol dan flavonoid. Dimana hasil uji secara in vitro dari golongan flavones dan fenol telah menunjukkan adanya respon imun (Lantapi dkk., 2011). Beberapa penelitian, menyebutkan bahwa Spirulina juga dapat digunakan sebagai zat antioxidan, imunomodulator dan anti-inflamasi (Wu Qinghua et al., 2016). Ekstraksi senyawa aktif dari mikroalga $S$. plantesis dibantu dengan menggunakan pelarut bertujuan untuk memperoleh hasil yang optimal baik jumlah ekstrak maupun senyawa aktif yang dikandung ekstrak. Pada umumnya pelarut yang sering digunakan adalah etanol karena etanol mempunyai polaritas yang tinggi, tidak beracun dan cenderung aman.

Pengobatan terhadap ikan yang terserang A. hydrophila dapat dilakukan dengan berbagai cara yaitu, melalui penyuntikan, perendaman, pengolesan dan melalui pakan. Pengobatan dengan sistem perendaman merupakan cara aplikatif dibanding dengan aplikasi lainnya, karena dapat mempermudah proses pengobatan terutama untuk ikan yang berukuran kecil dalam skala banyak. Penelitian ini bertujuan untuk melihat kondisi tingkat kekebalan tubuh pada tubuh dengan melihat jaringan organ limpa, kadar Ig-M dan diferensial leukosit pada ikan Mas setelahdiinfeksi $A$. hydrophila maupun sesudah direndam dengan S. plantesis. 


\section{Materi dan Metode}

Penelitian pemeliharaan ikan dilaksanakan di Fakultas Perikanan dan Kelautan, Universitas Airlangga. Uji Ig-M dengan ELISA dilakukan di Institute Tropical Desease Universitas, Airlangga Surabaya, Jawa Timur. Ektrasi etanol Spirulina plantesis dilakukan di Laboratorium Kering Fakultas Perikanan dan Kelautan Universitas Airlangga Surabaya. Pembuatan preparat histopatologi dilakukan di Laboratorium Histologi Fakultas Kedokteran Universitas Airlangga Surabaya.

Penelitian ini terdiri dari dua tahap yaitu tahapan uji pendahuluan dan tahapan uji utama. Uji pendahuluan terdiri dari ekstraksi $S$. plantesis menggunakan etanol 95\% untuk mendapatkan ekstrak, analisa komposisi kimia secara kualitatif dan revirulensi A. Hydrophila dan untuk mengaktifkan kembali bakteri tersebut.. Tahapan awal yang dilakukan yaitu menimbang S. platensis bubuk sebanyak 100 gram. Kemudian taruh dalam wadah beaker glass steril. Metode ekstraksi merupakan modifikasi penelitian El-Baz et al., (2013), dengan metode maserasi. Bubuk Spirulina dimaserasi dengan etanol $95 \%$ dengan volume (ml) empat kali berat sampel (gr). Ekstraksi dilakukan pada suhu ruang selama sehari kemudian disaring. Etanol kemudian dipisah dengan rotary evaporator pada suhu $50^{\circ} \mathrm{C}$. Hasil ekstrak berbentuk pekat dan padat.

Identifikasi senyawa metabolit dilakukan dengan uji kualitatif, uji ini menggunakan metode Kromatografi Lapis Tipis (KLT). Penentuan fenol dimulai dengan penimbangan sampel bubuk $S$. platensis sebanyak $10 \mu \mathrm{g}$ dilarutkan dengan 1 $\mathrm{ml}$ etanol 96\%, selanjutnya ektrak tersebut ditotolkan pada pelat KLT. Untuk fase gerak menggunakan kloroform : metanol (9:1). Setelah ditotolkan pelat tersebut dimasukkan pada bak yang berisi larutan fase gerak dan ditunggu sampai totolan pada pelat bergerak. Diamkan pelat tersebut setelah terjadi reaksi dan kemudian disemprotkan $\mathrm{FeCl}_{3}$ pada pelat KLT. Setelah itu, tunggu reaksinya dan amati pada KLT visualiser. Lihat reaksi noda, jika timbul warna hitam menunjukkan adanya fenol dalam ekstrak tersebut (Robinson, 1995).
Penentuan flavonoid yaitu menimbang ekstrak Spirulina sebanyak $10 \mu \mathrm{g}$ dilarutkan dengan $1 \mathrm{ml}$ etanol $96 \%$, selanjutnya ektrak tersebut ditotolkan pada pelat KLT. Fase gerak yang digunakan untuk uji flavanoid juga menggunakan kloroform : metanol (9:1). Setelah dititolkan pelat tersebut dimasukkan pada bak yang berisi larutan fase gerak dan ditunggu sampai totolan pada pelat bergerak. Diamkan pelat tersebut, setelah terjadi reaksi, kemudian disemprotkan $\mathrm{H}_{2} \mathrm{SO}_{4} 10 \%$. Setelah itu plat KLT dipanaskan di TLC plate heater dengan suhu $105^{\circ} \mathrm{C}$ dan ditunggu selama 5 menit. Flavanoid akan tampak berwarna hijau kebiruan dibawah sinar UV $366 \mathrm{~nm}$ dan untuk secara visual tampak noda berwarna kuning kecoklatan (Saravanakumar et al., 2009).

Revirulen bakteri digunakan untuk pengaktifan bakteri sebagai patogen, dimana injeksi bakteri $A$. hydrophila $10^{6} \mathrm{CFU} / \mathrm{ml}$ disuntikkan ke ikan mas dan ditunggu selang dua hari, setelah itu organ target seperti limpa dan ginjal di screeping. Hasil screeping di kultur di media agar TSA dan disimpan di ruang inkubator selama 24 jam agar tumbuh. Dan diujikan kembali dengan uji biokimia, setelah itu diidentifikasi dengan acuan Faddin (1980).

Ikan yang digunakan untuk penelitian adalah benih ikan mas ukuran 7$8 \mathrm{~cm}$ sebanyak 120 ekor. Setiap penelitian, akuarium uji diisi dengan 6 ekor ikan dan sebelum diberi perlakuan ikan uji diadaptasikan selama 7 hari. Ikan diinfeksi terlebih dahulu dengan dosis $10^{6} \mathrm{cfu} / \mathrm{ml}$. Perendaman ektrak S. platensis dilakukan setelah bakteri A. hydrophila diinfeksikan pada ikan Mas. Perendaman dilakukan selama 30 menit, perendaman ekstrak juga dilakukan 2x, yaitu hari kedua setelah diinfeksi dan selanjutnya hari ke lima. Untuk konsentrasi dosis perlakuan perendaman adalah sebagai berikut:

Kontrol negatif : Ikan disuntik dengan PBS tanpa direndam ekstrak.

Kontrol positif $\quad$ : Ikan diinfeksi bakteri A. hydrophila tanpa direndam ekstrak etanol S. Platensis

Perlakuan C diinfeksi A.hydrophila, 


$\begin{array}{ll} & \text { kemudian direndam } \\ & \text { ekstrak etanol } S . \\ & \text { platensis dengan dosis } 50 \\ & \text { ppm. } \\ \text { Perlakuan D } & \text { Ikan Mas yang } \\ & \text { diinfeksi A.hydrophila, } \\ & \text { Kemudian direndam } \\ & \text { ekstrak etanol } S . \\ & \text { platensis dengan dosis } \\ & \text { 100 ppm. } \\ \text { : Ikan Mas yang } \\ \text { Perlakuan E } \\ \text { diinfeksi A. hydrophila, } \\ \text { kemudian direndam } \\ \text { ekstrak etanol } S . \\ \text { platensis dengan dosis } \\ \text { 200 ppm. }\end{array}$

Parameter utama dalam penelitian ini yaitu mortalitas ikan mas, histopatologi organ limpa, uji Ig-M dengan ELISA dan diferensial leukosit sebelum diberi ekstrak serta maupun sesudahnya. Pengamatan mortalitas dilakukan selama 14 hari dengan parameter yang diamati baik parameter utama maupun pendukung

\subsection{Histopatologi Limpa}

Ikan segar ukuran $8 \mathrm{~cm}$ dibedah dan diambil organ limpa, kemudian direndam dalam larutan Buffered Neutral Formalin (BNF) 10\% dengan perbandingan 1:20 selama 48 jam. Metode histopatologi menggunakan metode yang sesuai dengan metode Meyers (2000) yaitu dehidrasi, clearing, infiltrasi paraffin, embedding, pembuatan preparat dan pewarnaan.

Setelah pembuatan preparat, dilakukan pemeriksaan dan skoring. Untuk menilai tingkat kerusakan jaringan ditentukan dengan analisis skoring sebagai berikut.
Tabel 1. Skoring jaringan limpa (Pantung

\begin{tabular}{|c|c|c|c|c|}
\hline $\begin{array}{c}\text { Param } \\
\text { eter } \\
\text { yang } \\
\text { diamat } \\
\text { i }\end{array}$ & $\begin{array}{c}\text { Skor 0 } \\
\text { (Norm } \\
\text { al) }\end{array}$ & $\begin{array}{c}\text { Skor 1 } \\
\text { (ringa } \\
\text { n) }\end{array}$ & $\begin{array}{c}\text { Skor } \\
2 \\
\text { (seda } \\
\text { ng) }\end{array}$ & $\begin{array}{l}\text { Skor } 3 \\
\text { (berat) }\end{array}$ \\
\hline $\begin{array}{c}\text { Konge } \\
\text { sti }\end{array}$ & $\begin{array}{c}\text { Tidak } \\
\text { ada } \\
\text { sama } \\
\text { sekali }\end{array}$ & $\begin{array}{c}\text { Kuran } \\
\text { g dari } \\
30 \% \\
\text { dari } \\
\text { luas } \\
\text { bidang } \\
\text { panda } \\
\text { ng }\end{array}$ & $\begin{array}{c}30 \%- \\
70 \% \\
\text { dari } \\
\text { luas } \\
\text { bidan } \\
\mathrm{g} \\
\text { pand } \\
\text { ang }\end{array}$ & $\begin{array}{c}\text { Lebih } \\
\text { dari } \\
70 \% \\
\text { dari } \\
\text { luas } \\
\text { bidang } \\
\text { pandan } \\
\text { g }\end{array}$ \\
\hline $\begin{array}{l}\text { Haem } \\
\text { osideri } \\
\text { n }\end{array}$ & $\begin{array}{c}\text { Tidak } \\
\text { ada } \\
\text { sama } \\
\text { sekali }\end{array}$ & $\begin{array}{c}\text { Kuran } \\
\text { g dari } \\
30 \% \\
\text { dari } \\
\text { luas } \\
\text { bidang } \\
\text { panda } \\
\text { ng }\end{array}$ & $\begin{array}{c}30 \%- \\
70 \% \\
\text { dari } \\
\text { luas } \\
\text { bidan } \\
\mathrm{g} \\
\text { pand } \\
\text { ang }\end{array}$ & $\begin{array}{c}\text { Lebih } \\
\text { dari } \\
70 \% \\
\text { dari } \\
\text { luas } \\
\text { bidang } \\
\text { pandan } \\
\text { g }\end{array}$ \\
\hline $\begin{array}{l}\text { Melan } \\
\text { o } \\
\text { macro } \\
\text { phage } \\
\text { center }\end{array}$ & $\begin{array}{c}\text { Tidak } \\
\text { ada } \\
\text { sama } \\
\text { sekali }\end{array}$ & $\begin{array}{c}\text { Kuran } \\
\text { g dari } \\
30 \% \\
\text { dari } \\
\text { luas } \\
\text { bidang } \\
\text { panda } \\
\text { ng }\end{array}$ & $\begin{array}{c}30 \%- \\
70 \% \\
\text { dari } \\
\text { luas } \\
\text { bidan } \\
\mathrm{g} \\
\text { pand } \\
\text { ang }\end{array}$ & $\begin{array}{c}\text { Lebih } \\
\text { dari } \\
70 \% \\
\text { dari } \\
\text { luas } \\
\text { bidang } \\
\text { pandan } \\
\text { g }\end{array}$ \\
\hline
\end{tabular}

\subsection{Uji konsentrasi Ig-M dengan Elisa}

Uji Ig-M mengguna kit ELISA dari Bioassay Technology Laboratory. Sampel uji yang digunakan untuk uji Ig-M diambil dari serum ikan mas. Alur kerja Elisa sesuai dengan operational manual yang ditetapkan oleh Bioassay Technology Laboratory yang nantinya setiap lubang diukur absorbansinya (OD) dengan ELISA reader. Setelah diketahui absorbansinya, dilakukan perhitungan regresi dan dihitung kemudian akan terkalkulasi nilai konsentrasi setiap perlakuan.

\subsection{Uji Diferntial Leukosit}

Kaca objek dibersihkan dengan alkohol, teteskan darah ikan uji sekitar $1 \mathrm{~cm}$ dari ujung sebelah kiri kaca objek, kemudian digeser kearah kanan sehingga darah 
tersebut akan menyebar sepanjang sisi kaca pemulas. Selanjutnya dikeringkan dan siap untuk diwarnai. Preparat apus tersebut difiksasi dengan metanol selama 3-5 menit dan dibiarkan kering. Preparat kemudian diwarnai dengan larutan giemza selama 30 menit. Selanjutnya preparat dicuci dengan aquades dan dibiarkan mengering di atas rak. Setelah kering preparat diperiksa di bawah mikroskop dengan perbesaran 400x dihitung setiap jenis leukosit menggunakan blood counter. Sel yang dihitung paling sedikit 100 sel dan dilakukan perhitungan persentase jenis leukosit.

\subsection{Kelulushidupan}

Kelulushidupan dapat dihitung dengan rumus (Effendi, 1997):

$$
\mathrm{SR}=\frac{\mathrm{Nt}}{\mathrm{No}} \times 100 \%
$$

Keterangan:

$\mathrm{Nt}$ : jumlah total ikan yang hidup pada akhir penelitian (ekor)

No : jumlah total ikan pada awal penelitian (ekor)

Parameter pendukung penelitian adalah pengukuran kualitas air berupa DO terlarut, $\mathrm{pH}$ dan suhu. Parameter pendukung dilakukan untuk melengkapi data dari parameter utama.

\section{Hasil dan Pembahasan}

Hasil identifikasi senyawa ekstrak etanol $S$. platensis dapat ditunjukkan pada Tabel 2.

Tabel 2. Hasil identifikasi golongan senyawa metabolit sekunder ekstrak etanol $S$. platensis

\begin{tabular}{|l|l|l|l|}
\hline $\begin{array}{l}\text { Bahan } \\
\text { (Spesie } \\
\text { s) }\end{array}$ & $\begin{array}{l}\text { Uju } \\
\text { fitokimi } \\
\text { a }\end{array}$ & $\begin{array}{l}\text { Marliana } \\
\text { dkk, } \\
\mathbf{2 0 0 5}\end{array}$ & Hasil \\
\hline $\begin{array}{l}\text { Spirulin } \\
\text { a } \\
\text { platensi } \\
\text { s }\end{array}$ & Fenol & $\begin{array}{l}\text { Biru tua/ } \\
\text { hitam } \\
\text { kehijauan }\end{array}$ & $\begin{array}{l}\text { (+) Hijau } \\
\text { kehitama } \\
\text { n }\end{array}$ \\
\cline { 2 - 4 } & $\begin{array}{l}\text { Flavonoi } \\
\text { d }\end{array}$ & $\begin{array}{l}\text { Fluoresen } \\
\text { si } \\
\text { kecoklata } \\
\text { n intensif }\end{array}$ & $\begin{array}{l}\text { Kecoklata } \\
\text { n }\end{array}$ \\
\hline
\end{tabular}

Sedangkan hasil uji kromatografi lapis tipis pada gel silica ditunjukkan pada gambar dibawah ini
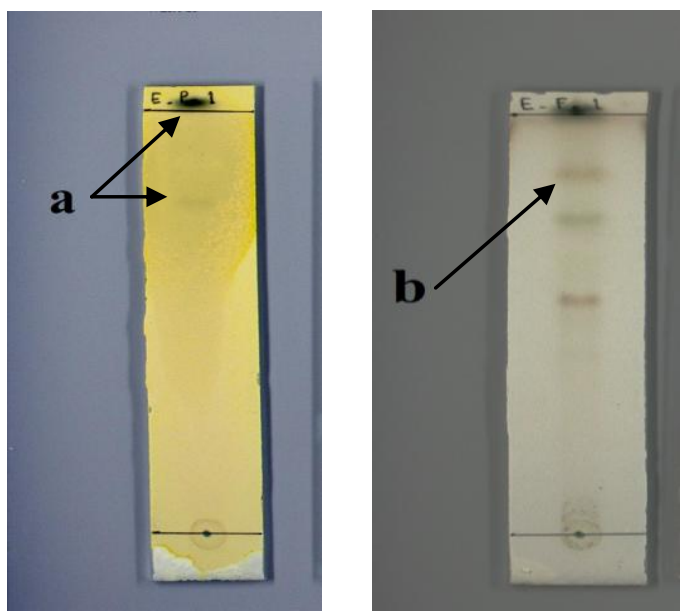

Gambar 1. Hasil uji pada Kromatografi Lapis Tipis (KLT), (a) Positif fenol (b) Positif flavonoid

Ikan Mas yang terserang A.hydrophila menunjukkan gejala hemoragi pada kulit, warna kulit menjadi pucat serta mengalami geripis pada sisik. Untuk organ dalam seperti limpa, organ tersebut terlihat berwarna merah pucat. Ikan nampak mengalami gejala klinis secara merata sekitar 1 hari. Setelah itu ikan uji diberikan perlakuan perendaman dengan menggunakan ekstrak etanol S. platensis selama 30 menit. Dibawah ini merupakan Gambar 2. ikan normal dan ikan yang setelah diinfeksi bakteri A.hydrophila.

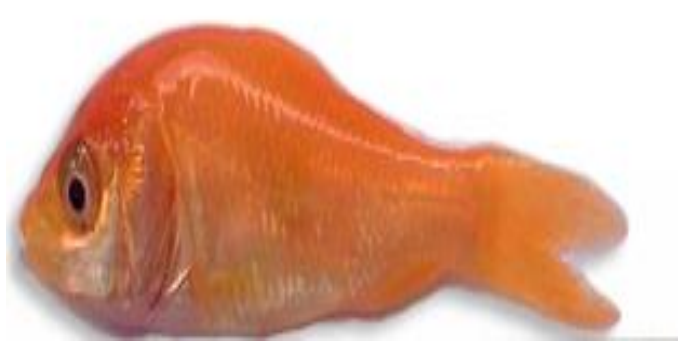

(a) 


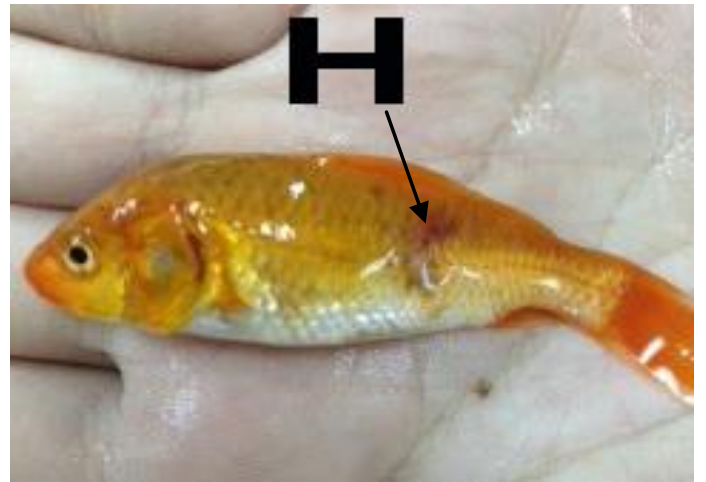

(b)

Gambar 2. Ikan Mas. (a) Ikan Mas Normal atau sehat, (b) Ikan Mas yang terinfeksi $A$. hydrophila (h) Haemoragi.

\subsection{Kadar IgM}

Pada penelitian ini, pengambilan sampel untuk uji IgM yang diambil adalah serum darah ikan. Pengukuran kadar IgM dilakukan setelah perendaman kedua ekstrak S. platensis, yaitu pada hari ke-8. Hasil penelitian pengukuran Ig-M pada ikan mas menunjukkan, bahwa konsentrasi Ig-M paling tinggi pada perlakuan dosis $100 \mathrm{ppm}$ $(1463,89 \mu \mathrm{g} / \mathrm{ml})$, yang berbeda nyata dengan perlakuan dosis $50 \mathrm{ppm}(963 \mu \mathrm{g} / \mathrm{ml})$, kontrol positif $(843,72)$, perlakuan dosis $200 \mathrm{ppm}$ $(672,046 \mu \mathrm{g} / \mathrm{ml})$ dan kontrol negatif $(617,247 \mu \mathrm{g} / \mathrm{ml})$. Konsentrasi IgM paling rendah pada perlakuan kontrol negatif $(617,247 \mu \mathrm{g} / \mathrm{ml})$. Dibawah ini adalah gambaran grafik konsentrasi Ig-M antar perlakuan penelitian.

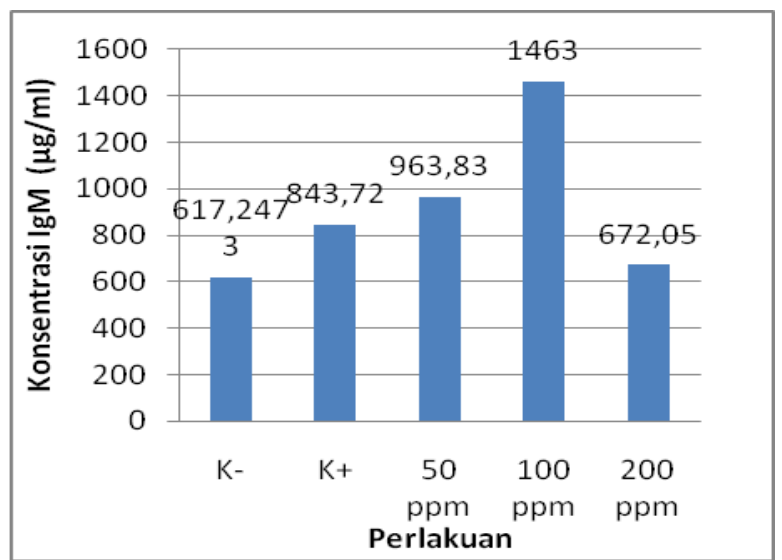

Gambar 3. Grafik konsentrasi Ig-M antar perlakuan setelah rendam kedua, pada hari ke-8.

\subsection{Histopatologi Limpa}

Limpa merupakan salah satu organ yang berperan dalam sistem kekebalan tubuh. Limpa yang normal berwana merahungu karena kandungan darahnya. Gambar 2 menunjuukkan histopatologi limpa kontrol positif dan kontrol negatif.

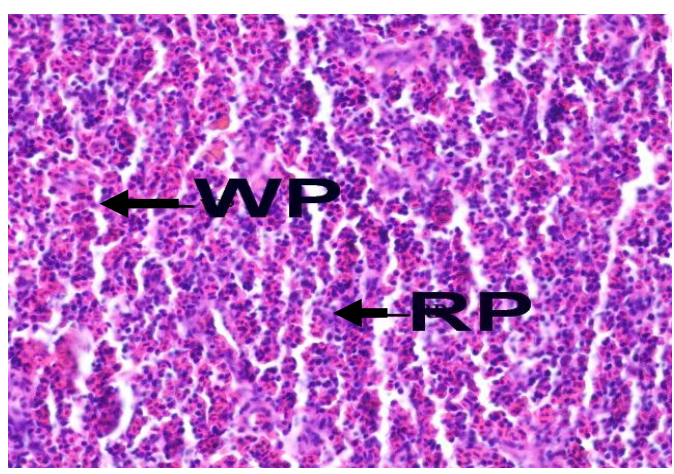

(i)

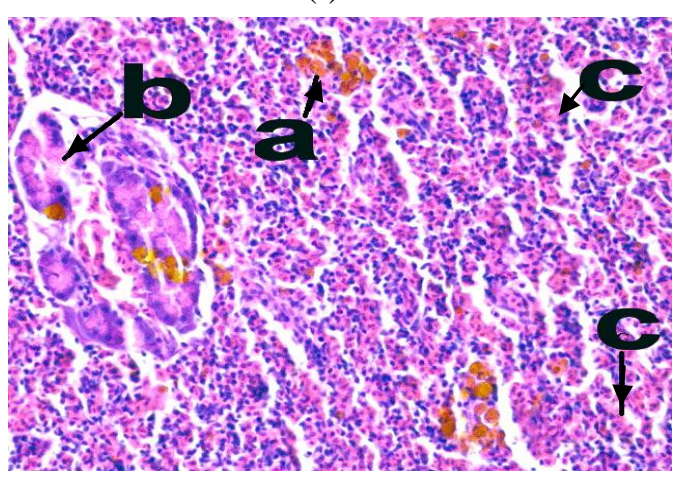

(ii)

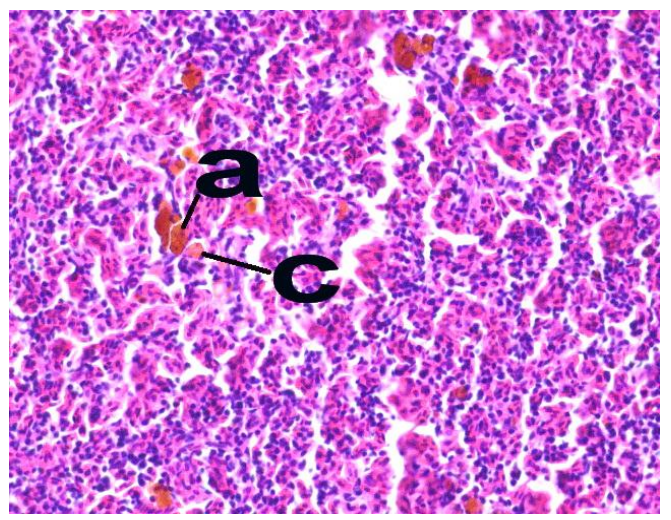

(iii) 


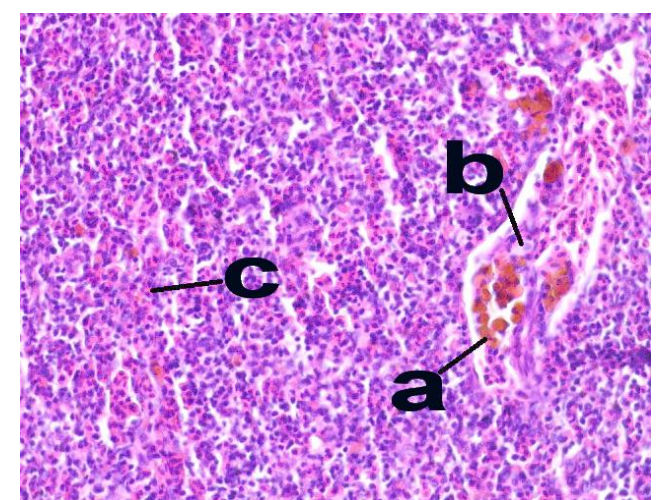

(iv)

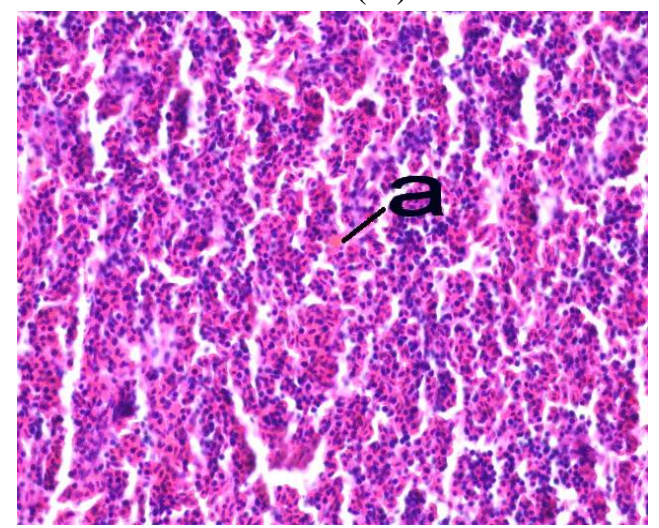

(v)

Gambar 4. Histopatologi Limpa Ikan Mas (Pembesaran 400x)

Keterangan :

i. Kontrol negatif

ii. Kontrol positif

iii. Dosis $50 \mathrm{ppm}$

iv. Dosis $100 \mathrm{ppm}$

v. Dosis $200 \mathrm{ppm}$
a. Hemosiderin
b. Kongesti
c. Melanomakrofag
WP. White pulp
RP. Red pulp

Hasil skoring tingkat kerusakan jaringan antar perlakuan dijumlah kerusakannya dan dirata-rata, kemudian dilakukan analisis dengan uji Kruskal Wallis. Dibawah ini adalah hasil skoring uji Kruskal Wallis yang dilanjutkan dengan uji Mann Whitney

Tabel 3. Rata-rata scoring Histopat Limpa

\begin{tabular}{|c|c|}
\hline Perlakuan & Mean Rank \\
\hline Kontrol - & $3.17^{(\mathrm{cd})}$ \\
Kontrol + & $14.00^{\text {(a) }}$ \\
Dosis 50 ppm & $9.50^{\text {(b) }}$ \\
Dosis 100 ppm & $8.17^{\text {(bc) }}$ \\
Dosis 200 ppm & $4.33^{(\mathrm{c})}$ \\
\hline
\end{tabular}

Hasil Tabel 2 menunjukkan perlakuan $\mathrm{K}+$ berbeda nyata dengan perlakuan dosis $50 \mathrm{ppm}$, dosis $100 \mathrm{ppm}$, dosis 200 ppm dan K-. Perlakuan K+ mempunyai nilai kerusakan yang paling tinggi dari perlakuan lainnya, sementara perlakuan dosis $50 \mathrm{ppm}$ dan $100 \mathrm{ppm}$ menunjukkan tingkat kerusakan yang tidak berbeda nyata, diikuti dengan perlakuan dosis 200 ppm. Perlakuan kontrol negatif berbeda juga dengan perlakuan lainnya, dan perlakuan ini menunjukkan tingkat kerusakan yang paling rendah.

\subsection{Diferensial Leukosit}

Berdasarkan

granulasi sitoplasmanya, leukosit dibedakan menjadi granuler meliputi basofil, eosinofil, dan neutrofil, serta agranuler meliputi limfosit dan monosit. Berikut ini adalah gambaran grafik hasil pengamatan limfosit setelah perendaman kedua.

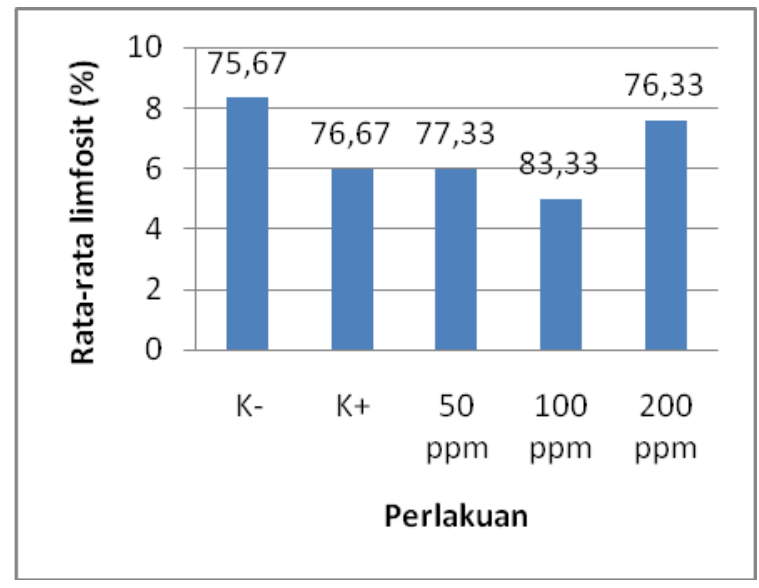

Gambar 5. Grafik rata-rata nilai limfosit setelah perendaman kedua

Limfosit adalah sel yang kompeten secara imunologik dan membantu fagosit dalam pertahanan tubuh terhadap infeksi dan invasi asing lainnya. Hasil rata-rata jumlah limfosit paling tinggi ditunjukkan pada perlakuan dosis $100 \mathrm{ppm}(83,33 \%)$ yang berbeda nyata dengan perlakuan $\mathrm{K}-, \mathrm{K}+, 50$ ppm dan 200 ppm. Jumlah limfosit terendah pada perlakuan K- $(75,67 \%)$. 


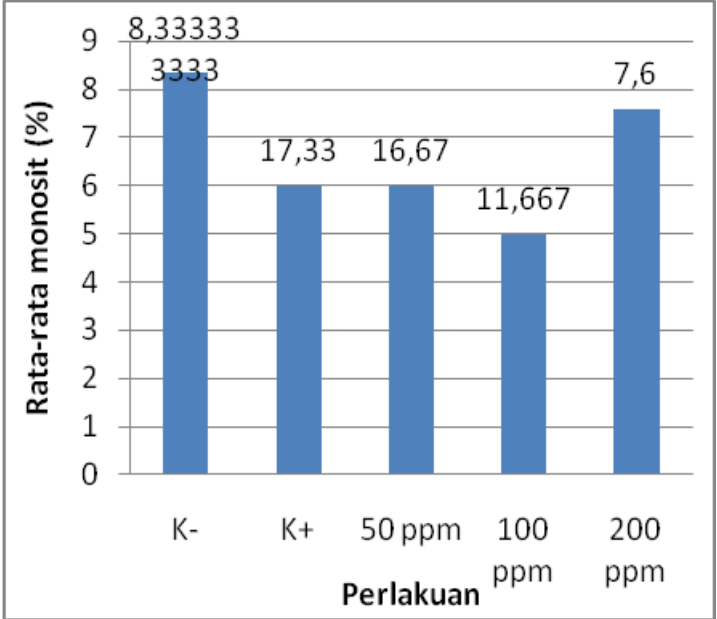

Gambar 6. Grafik rata-rata nilai monosit setelah perendaman kedua

Monosit merupakan salah satu leukosit yang berinti besar dengan ukuran $2 \mathrm{x}$ lebih besar dari eritrosit dan diproduksi di jaringan limpatik. Pada Gambar 6 menunjukkan kontrol positif $(17,33 \%)$ tidak berbeda nyata dengan perlakuan dosis 50 ppm $(16,67 \%)$. Jumlah monosit tertinggi pada kontrol positif yaitu perlakuan yang diinfeksi tanpa diobati. Perlakuan dosis 100 ppm $(11,67 \%)$ berbeda nyata dengan perlakuan lainnya, dimana jumlah monositnya sangat rendah dibanding dengan perlakuan lainnya.

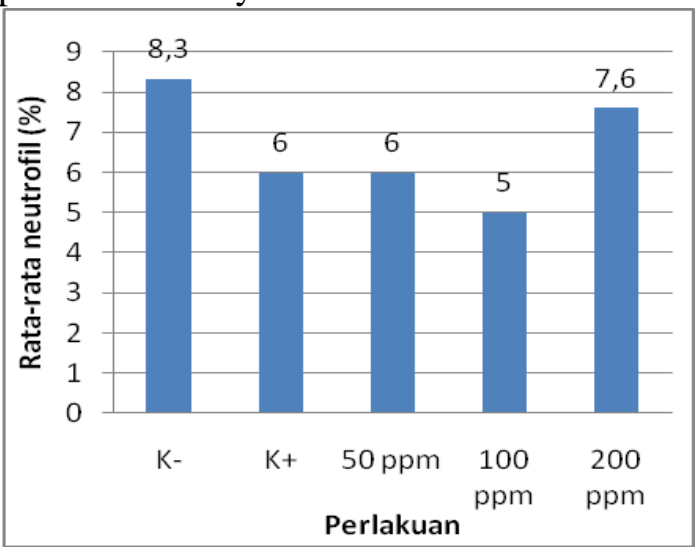

Gambar 7. Grafik rata-rata nilai neutrofil setelah perendaman kedua.

Neutrofil merupakan sel-sel pertama yang meninggalkan pembuluh darah yang penting karena mengandung vakuola yang berisi enzim untuk menghancurkan organisme yang dihancurkannya. Gambar 7. menunjukkan jumlah neutrofil ikan Mas dengan nilai yang bervariasi dan tiap perlakuan terlihat berbeda nyata. Nilai neutrofil pada perlakuan K- $(8,33 \%)$ dan dosis 200 ppm $(7,67 \%)$ tidak berbeda nyata, dan perlakuan kontrol positif $(6,00 \%)$, dosis $50 \mathrm{ppm}(6,00 \%)$ juga tidak berberbeda nyata antar perlakuan. Perlakuan dosis $100 \mathrm{ppm}$ $(5,00 \%)$ juga mempunyai nilai rata-rata neutrofil paling kecil dari perlakuan lainnya.

\subsection{Kelulushidupan}

Kelulushidupan ikan dalam suatu proses budidaya merupakan parameter keberhasilan dalam berbudidaya. Dibawah ini adalah gambar 2, yaitu grafik gambar kelulushidupan ikan mas selama penelitian.

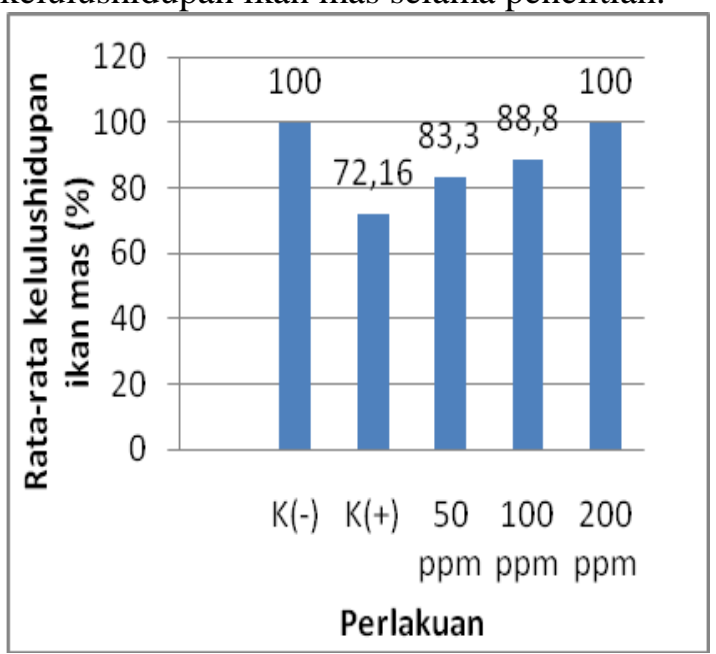

Gambar 8. Grafik tabel rata-rata kelulushidupan ikan mas selama penelitian.

Pada Gambar 8, data menunjukkan persentase kelulushidupan hidup benih ikan mas tertinggi dicapai pada perlakuan dosis $200 \mathrm{ppm}$ dan kontrol negatif (100\%), perlakuan dosis $100 \mathrm{ppm}(88,8 \%)$ dan dosis $50 \mathrm{ppm}(83,33 \%)$, tidak berbeda nyata dengan perlakuan dosis $200 \mathrm{ppm}$ dan kontrol negatif. Tetapi perlakuan dosis $50 \mathrm{ppm}$ dan 100 ppm berbeda nyata dengan perlakuan kontrol positif $(72,16 \%)$.

\subsection{Kualitas air}

Beberapa parameter kualitas air yang diukur dalam penelitian ini adalah suhu, $\mathrm{pH}$ dan oksigen terlarut (DO). Berikut ini adalah hasil range pengukuran kualitas air selama penelitian. 
Tabel 4. Kualitas air selama penelitian

\begin{tabular}{|l|c|c|c|}
\hline Perlakuan & $\begin{array}{c}\text { Suhu } \\
\left({ }^{\mathbf{}} \mathbf{C}\right)\end{array}$ & $\mathbf{p H}$ & $\begin{array}{c}\text { DO } \\
(\mathbf{m g} / \mathbf{l})\end{array}$ \\
\hline Kontrol (+) & 29,6 & 7,33 & 6,2 \\
\hline Kontrol (-) & 29,8 & 7,33 & 6,15 \\
\hline $\begin{array}{l}\text { Dosis 50 } \\
\text { ppm }\end{array}$ & 29,4 & 7,27 & 6,2 \\
\hline $\begin{array}{l}\text { Dosis 100 } \\
\text { ppm }\end{array}$ & 29,6 & 7,21 & 6,16 \\
\hline $\begin{array}{l}\text { Dosis } 200 \\
\text { ppm }\end{array}$ & 29,7 & 7,15 & 6,2 \\
\hline Kisaran & $25-30$ & $\begin{array}{c}6,5- \\
8,5\end{array}$ & $>5$ \\
\hline
\end{tabular}

Data pengukuran kualitas air menunjukkan nilai parameter kualitas air yaitu: suhu $29^{\circ} \mathrm{C}, \mathrm{pH} 7$, dan DO $6 \mathrm{mg} / \mathrm{L}$.

\subsection{Pembahasan}

Perlawanan terhadap benda asing, tubuh memiliki sistem pertahanan yang saling mendukung, baik sistem imun spesifik maupun non spesifik. Apabila sistem imun non spesifik tidak mampu mengeliminasi agen penyakit, maka immunoglobulin akan membantu sistem tubuh sebagai pertahanan kedua (Nagael et al., 1994). Pada penelitian ini, hasil konsentrasi IgM yang diuji merupakan konsentrasi IgM secara keseluruhan pada tubuh ikan Mas. Konsentrasi IgM pada penelitian paling tinggi pada perlakuan dosis $100 \mathrm{ppm}$ $(1463,89 \mu \mathrm{g} / \mathrm{ml})$, hal ini dikarenakan ektrak tersebut memacu peningkatan proliferasi limfosit. Hal ini sesuai dengan pernyataan Jose et al., (2014) bahwa kandungan flavonoid berpotensi meningkatkan proliferasi limfosit, meningkatkan jumlah sel T serta sel B dan meningkatkan aktivitas IL2. Dengan adanya peningkatan immunoglobulin, antibodi IgM berusaha untuk melawan antigen yang terdapat pada tubuh ikan. Peningkatan limfosit akan mengalami pembelahan atau diferensiasi menjadi sel plasma, dan sel plasma akan memproduksi dan melepaskan ribuan antibodi yang nantinya memasuki peredaran darah yang siap untuk menempel pada antigen (Uribe et al., 2011). Perlakuan dosis $50 \mathrm{ppm}(963 \mu \mathrm{g} / \mathrm{ml})$, berbeda nyata juga dengan perlakuan Kontrol positif. Perlakuan konsentrasi paling rendah pada kontrol negatif $(617,247 \mu \mathrm{g} / \mathrm{ml})$. Pada perlakuan kontrol negatif, konsentrasi IgM pada ikan Mas dengan ukuran benih menunjukkan pada kisaran normal yaitu sekitar 600-800 $\mu \mathrm{g} / \mathrm{ml}$ (Abedi et al., 2013). Perlakuan dosis $200 \mathrm{ppm}(672 \mu \mathrm{g} / \mathrm{ml})$ juga menunjukkan kisaran IgM normal, kemungkinan karena perendaman ekstrak S. platensis kedua dapat mengembalikan kekebalan tubuh ikan yang terserang bakteri, sehingga hanya sistem non spesifik yang bekerja dalam tubuh apabila masih terdapat antigen.

Analisis histopatologi ini bertujuan untuk mengetahui tingkat kesembuhan dengan melihat tingkat kerusakan jaringan pada organ limpa setelah perendaman yang dibandingkan dengan histolopatologi limpa ikan sehat dan ikan sakit. Hasil skoring pengamatan menunjukkan, tingkat kerusakan tertinggi pada perlakuan kontrol positif. Perlakuan Kontrol positif tampak pada pengamatan banyak mengalami kongesti, pecahnya protein sel darah merah (hemosiderin) dan mengalami melano makrophag. Pembentukan melano makrophag karena racun toksin yang dikeluarkan bakteri Aeromonas hydrophila mengalir masuk ke dalam sel endotel pembuluh darah yang akan menyebabkan kerusakan pada jaringan endotel sehingga akan merangsang pembentukan MMC (David and Kartheek, 2015). Perlakuan yang memperlihatkan jumlah skoring paling rendah ada pada perlakuan kontrol negatif. Pemberian dosis perandaman 200 ppm ekstrak S. plantesis pada benih ikan mas yang diinfeksi bakteri $A$. hydrophila mengalami penyembuhan yang baik dengan memperlihatkan kondisi histopatologi jaringan limpa yang mempunyai jumlah MMC sedikit dan kondisi mendekati limpa ikan normal. Senyawa fenol berfungsi sebagai antibakteri dan antioksidan, sehingga dapat melindungi jaringan tubuh dari radikal bebas. Menurut Wu Qinghua et al., (2016) bahwa S. platensis mempunyai kandungan senyawa fenol dan flavanoid, sebagai immunomodulatot, antiinflamation dan antioksidan sehingga dapat menjaga sistem tubuh dan jaringan tubuh ikan dari adanya patogen.

Hasil penelitian menunjukkan bahwa nilai rataan limfosit paling tinggi pada perlakuan dosis 100 ppm $(83,33 \%)$ berbeda nyata dengan perlakuan kontrol negatif, kontrol positif, $50 \mathrm{ppm}$ dan 200 
ppm. Peningkatan dosis ektrak S. plantesis dalam perendaman meningkatkan poliferasi dari sel-sel limfosit. Karena pada perendaman pertama, ektrak belum melindungi dan menstimulasi sistem tubuh dengan baik, sehingga pada perendaman kedua, ekstrak dapat membantu meningkatkan sel limfosit dalam memfagosit bakteri. Hal ini juga sesuai dengan pengamatan yang dilakukan Rustikawati (2012), tentang titer antibodi dan indeks fagositos, dimana ikan yang diuji setelah diberi ektrak Sargasum sebagai immunomodulator mempumyai nilai indeks fagosit dan titer antibodi yang lebih tinggi dibanding dengan ikan kontrol yang tanpa diberi apapun.

Hasil penelitian nilai monosit menunjukkan perlakuan kontrol positif $(17,33 \%)$ tidak berbeda nyata dengan perlakuan dosis $50 \mathrm{ppm}(16,67 \%)$. Jumlah monosit tertinggi pada kontrol positif yaitu perlakuan yang diinfeksi tanpa diobati. Meningkatnya jumlah monosit karena ikan masih mengalami infeksi bakteri $A$. hydrophila dengan tampak luka pada kulit. Perlakuan dosis 200 ppm (16,00\%) juga tidak berbeda nyata dengan kontrol negatif $(16,00 \%)$. Perlakuan dosis 100 ppm $(11,67 \%)$ berbeda nyata dengan perlakuan lainnya, dimana jumlah monositnya sangat rendah dibanding dengan perlakuan lainnya, hal ini dikarenakan adanya respon keseimbangan darah terhadap peningkatan proporsi jenis sel leukosit yang lainnya (limfosit dan neutrofil). Persentase monosit hasil pengamatan ini masih berada di dalam kisaran nilai normal pada semua perlakuan. Hasil rata-rata nilai absolut monosit pada penelitian ini menunjukkan 3.700-5.300 $\mathrm{sel} / \mathrm{mm}^{3}$.

Nilai rata-rata neutrofil paling tinggi tampak pada perlakuan kontrol negatif $(10,66 \%)$. Tingginya jumlah neutrofil, kemungkinan karena pengambilan sampel darah pada hari ke-8. Ikan kontrol negatif tidak diinfeksi oleh bakteri, tetapi tubuh ikan mas membentuk sistem pertahanan tubuh non spesifik sehingga neutrofil tetap diproduksi oleh limfa untuk dikirim ke tempat adanya antigen yang masuk. Perlakuan dosis 100 ppm $(5,00 \%)$ mempunyai nilai rata-rata neutrofil paling kecil dari perlakuan lainnya. Kecilnya nilai neutrofil diperkiran karena berkurang infeksi akibat serangan antigen. Hal ini sesuai dengan pendapat Cahyaningsih dkk., (2007) yaitu setelah proses infeksi, jumlah sel neutrofil dapat ditekan, sel-sel mati dan jaringan nekrotik yang salah satunya mengandung neutrofil yang telah mati secara bertahap mengalami autolisis dalam beberapa hari.

Persentase kelulushidupan ikan mas tertinggi diperoleh pada perlakuan Kontrol negatif dan dosis 200 ppm (100\%), diikuti perlakuan dosis $100 \mathrm{ppm}(88,8 \%)$ dan 50 ppm (83,33\%). Perlakuan Kontrol positif mempunyai nilai kelangsungan hidup yang rendah dari yang lain, karena pada perlakuan ini ikan diinfeksi bakteri dan tidak direndam dengan ekstrak etanol $S$. platensis. Nilai kelangsungan hidup ikan mas dari masingmasing perlakuan penelitian setelah perendaman dianggap cukup baik yaitu berkisar antara $72-100 \%$. Hal ini sesuai dengan penelitian Retnoningsih., dkk (2009) bahwa tingkat kelangsungan hidup ikan Mas yang diinfeksi $A$. hydrophila dan diberi obat kanamycin yaitu sekitar $80 \%$. Perlakuan Kdan dosis 200 ppm tidak mengalami kematian, karena pada dosis 200 ppm, ektrak dapat membunuh dan menjaga sistem tubuh benih ikan mas dari serangan bakteri. Adanya kandungan senyawa fenol pada ekstrak S. platensis, juga dapat membantu membunuh bakteri patogen. Hal ini sesuai dengan pernyataan El Baz et al., 2003 bahwa senyawa fenol bekerja sebagai antibakteri. Ikan uji pada perlakuan dosis $150 \mathrm{ppm}$ dan 50 ppm menurun kelulushidupannya karena kemungkinan perlakuan perendaman kurang membunuh bakteri $A$. hydrophila sehingga belum menyembuhkan luka pada tubuh ikan, sehingga ikan tidak bisa bertahan lama.

Menurut Bachtiar (2002), suhu yang optimal untuk ikan mas yaitu sekitar $25^{\circ}-30^{\circ}$ C. Suhu yang terdapat pada media pemeliharaan berkisar antara $28^{\circ} \mathrm{C}-30^{\circ} \mathrm{C}$ dan masih dalam kisaran optimal, sehingga mendukung kehidupan ikan Mas selama penelitian. Derajat keasaman $(\mathrm{pH})$ selama penelitian berkisar antara 7-8. Dalam kondisi ini derajat keasaman $(\mathrm{pH})$ dalam media pemeliharaan masih dibawah batas tertinggi yaitu 11 (Zonneveld dkk., 1991), sehingga ikan dalam media pemeliharaan masih dapat 
hidup dengan normal. Biasanya angka $\mathrm{pH}$ dalam perairan air tawar dapat dijadikan indikator dari adanya keseimbangan unsurunsur kimia dan dapat mempengaruhi ketersediaan unsur-unsur kimia dan unsurunsur hara yang sangat bermanfaat bagi kehidupan organisme akuatik. Kandungan oksigen terlarut (DO) selama penelitian berkisar antara 6,1-6,2 mg/L. Menurut Bachtiar (2002), kandungan oksigen yang baik untuk ikan Mas yaitu sekitar $5-7$ $\mathrm{mg} / \mathrm{L}$.

\section{Kesimpulan}

Pemberian ekstrak etanol $S$. platensis pada ikan mas memberikan respon imun non-spesifik dan imun spesifik yang lebih baik dibandingkan dengan kontrol. Pemberian ekstrak etanol S. platensis telah meningkatkan jumlah Ig-M ikan mas pada perendaman terakhir dengan dosis terbaik yaitu 100 ppm dengan kenaikan konsentrasi sebesar $1463(\mu \mathrm{g} / \mathrm{ml})$, nilai prosentase limfosit, monosit dan neutrofil juga lebih baik pada ikan-ikan yang direndam ekstrak dibandingkan ikan kontrol. dan keadaan struktur jaringan limpa ikan mas terlihat seperti kontrol negatif.. Sedangkan kelangsungan hidup ikan selama penelitian menunjukkan bahwa peningkatan dosis ekstrak etanol S.platensis yang diberikan, memberikan proteksi yang lebih baik pada ikan ditandai dengan peningkatan kelulushidupan ikan mas.

\section{Saran}

Kandungan senyawa ekstrak etanol S.platensis dapat dilakukan penelitian lanjutan untuk perendaman pada bakteri selain A. hydrophila yang menyerang ikan, baik ikan air tawar maupun air laut.

\section{Daftar Pustaka}

Abdel,D.M.M., S.M Farouk and F.F. Madkour.2015. Anti-inflammatory and imunomodulatory effects of Spirulina platensis in comparison to Dunaliella salina in acetic acidinduced rat experimental colitis. Immunopharmacol Immunotoxicol. 37(2):126-139.
Abedi, Z., M.K.Khalesi and S.K,Eskandari. 2013. Biochemical and Hematological Profiles Of Common Carp (Cyprinus carpio) under Sublethal Effects of Trivalent Chromium. Departement of Fisheries, Faculty of Animal Science and Fisheries, SANRU, Iran. Iranian Journal of Toxicology. Vol 7, No 20.

Amrullah. 2004. Penggunaan Immunostimulan Spirulina platensis Untuk Meningkatkan Ketahanan Tubuh Ikan Koi Terhadap Virus Herpes. Sekolah Pascasarjana IPB.

Azizah, R. 2013. Uji Efektivitas Ekstrak Daun Teh Tua (Camellia sinensis) terhadap Penyakit Motile Aeromonas Septicemia pada Benih Ikan Mas. Thesis. Universitas Padjajaran. Hal 31-32.

Bachtiar, Y. 2002. Pembesaran Ikan Di Kolam Pekarangan. Jakarta : AgroMedia Pustaka. Hal 23.

Cahyaningsih,U., Hanik, M Dan Y.E Hedianto.2007. Diferensial Leukosit Pada Ayam Setelah Diinfeksi Eimeria Tenella Dan Pemberian Serbuk Kunyit (Curcuma Domestica) Dosis Bertingkat. Seminar Nasional Teknologi Peternakan dan Veteriner. Fakultas Kedokteran Hewan Institut Pertanian Bogor. hal 1-7.

Cipriano,C.R. 2001. Aeromonas Hydrophila and Motile Aeromonad Septicemias Of Fish. United States Departement Of The Interior Fish and Wildlife Service Division of Fishery Research Washington. USA.

David, M and R.M. Kartheek. 2015. Histopathological alterations in spleen of freshwater fish Cyprinus carpio exposed to sublethal concebtration of sodium cyanide. Environmental and Molecular Toxicology Laboratory, Department of PG Studies and Research in Zoology, India. Veterinary Journal. Vol 5 (1) : 1-5. 
Effendie, M.I. 1997. Biologi Perikanan. Yayasan Pustaka Nusatama. Yogyakarta. hal 45.

El-Baz,F.K., $\quad$ El-Senousy,W.M.,ElSayed,A.B and Kamel. 2013. In vitro antiviral and antimicrobial activitie of Spirulina plantesis extract. Journal Of Applied Pharmaceutical Science. Vol 3(12),pp 52-56.

Faddin,M. J.F.1980. Biochemical Tests for Identification of Medical Bacteria. Second Edition. Williams \& Wilkins. Baltimore/London.

Jose,J.,S. Sudhakaran., S. Kumar T.M2., S. Jayaraman and J. Variyar. 2014. Study of In vitro Immunomodulatory Effect of Flavonoid Isolated from Phyllanthus niruri on Human Blood Lymphocytes and Evaluation of its Antioxidant Potential. International Journal of Pharmacognosy and Phytochemical Research Vol; 6(2); 284-289.

Hernawati, R.D., Triyanto dan Murwantoko. Studi Pengaruh Karboksimetil Kitosan Terhadap Sistem Pertahanan Tubuh Non Spesifik Pada Ikan Mas (Cyprinus carpio). Jurusan Perikanan. Universitas Gajah Mada. Jurnal Sains Veteriner. ISSN :0126-0421.

Lantapi, N.C., M.A. Manggau dan G. Alam. 2011. Uji Efek Jus Buah Mengkudu (Morinda Citrifolia Linn.) Terhadap Aktivitas Imunoglobulin M (IgM) Dan Imunoglobulin G (IgG) Pada Mencit (Mus Musculus). Majalah Farmasi dan Farmakologi, Vol. 15, No. 2. hal. 99 - 104.

Mangunwardoyo, W., R. Ismayasari dan E. Riani. 2010. Uji Patogenisitas dan Virulensi Aeromonas hydrophila Stanier pada Ikan Nila (Oreochromis niloticus Lin.) melalui Postulat Koch. J. Ris. Akuakultur Vol. 5 Tahun 2010: 245-255.
Marliana,S.D.,Venty,S. dan Suyono. 2005. Skrining Fitokimia dan Analisis Kromatografi Lapis Tipis Komponen Kimia Buah Labu Siam (Sechium edule Jacq. Swartz.) dalam Ekstrak Etanol. Jurusan Kimia FMIPA Universitas Sebelas Maret (UNS) Surakarta. Biofarmasi,Vol 26-31.

Meyers,T.R.Ph.D. 2000. Fish Pathology Section Laboratory Manual. Alaska Departement Of Fish and Game Commercial Fisheries Division. Juneau. Alaska. Pp 159-164.

Muralidharan, L. 2014. Haematological Alterations In Fresh Water Fish Cyprinus Carpio (Linn) Exposed To Organophosphorous Pesticide Fenthion. P.G. Department of zoology, University of Mumbai., V.K. Krishna Menon college of commerce and Sharad Dighe college of science, Bhandup, India. ISSN: $2348-604$.

Nagael,M., H. Fuda., K. Ura ., H. Kawamura., S. Adachi., A. Hara and K. Yamauchil. 1994. The effect of cortisol administration on blood plasma immunoglobulin M (IgM) concentrations in masu salmon (Oncorhynchus masou). Fish Physiology and Biochemistry vol. 13 no. 1 pp 41-48.

Pantung., N., K.G. Helander., H. F. Herlander. and V. Cheevaporn. 2008. Histopathological Alterations of Hybrid Walking Catfish (Clarias macrocephalus x Clarias gariepinus) in Acute and Sub acute Cadmium Exposure. Environment Asia 1 : page 22-27.

Pratheepa and Sukumaran. 2014. Effect of Euphorbia hirta plant leaf extract on immunostimulant response of Aeromonas hydrophila infected Cyprinus carpio. Peer J Journal. Vol 2.pp 671-688. 
Retnoningsih,S.,

Kamiso,H.N.,

K.Lanadimulya.,

Suprayogi.,

Supardi.,D.

Darmantani.,I

.P.Panca.,Hasnah dan Milis.

Efektivitas Kanamycin Terhadap

Furunculosis Pada Karper, Cyprinus carpio. Jurnal Perikanan. 192-200 ISSN: 0853-6384.

Robinson, T. 1995. Kandungan Organik Tumbuhan Tinggi, edisi keenam, Departement of Biochemistry University of Massachussetts, diterjemahkan oleh Kosasih, P.Penerbit ITB. Bandung. Hal : 157198.

Rustikawati,I. 2012. Efektivitas Ekstrak Sargassum sp. Terhadap Diferential Leukosit Ikan Nila (Orechromis niloticus) Yang Diinfeksi Streptococcus iniae. Universitas Padjajaran. Jurnal Akuatika, Vol 3.No 2.hal 125-134.

Saravanakumar, A., Venkateshwaran, K., Vanitha, J., Ganesh, M., Vasudevan, M., and Sivakumar, T., 2009. Evaluation of Antibacterial Activity, Phenol and Flavonoid Contents of Thespesia populnea Flower Extracts. Pak. J. Pharm. Sci., Vol. 22(3): 282286.

Wu Qianghua, Lian,L.,Anca,M., Blanka,K., Dan, W and K, Kuc. 2016. The antioxidant, immunomodulatory, and anti-inflammatory activities of Spirulina: an overview. University of Hradec Králové. Springer. Pp 1-27.

Uribe,C. H. Folch., R. Enriquez and G. Moran. 2011. Innate and adaptive immunity in teleost fish: a review. Veterinarni Medicina Journal.Vol 56. pp 486-503.

Zonneveld, N.E.A. Huisman dan J.H. Bon. 1991. Prinsip-Prinsip Budidaya Ikan. Jakarta: PT. Gramedia Pustaka Utama. 